\title{
PENGARUH SUDUT KEMIRINGAN (INKLINASI) TERHADAP UNJUK KERJA AYAKAN GETAR (VIBRATING SCREEN)
}

\author{
Haris Mujianto ${ }^{1)}$, dan Miftahul Rahmi ${ }^{2)}$, \\ ${ }^{1)}$ Teknik Mesin, Teknik, Universitas PGRI Banyuwangi \\ ${ }^{2)}$ Pendidikan Matematika, FMIPA, Universitas PGRI Banyuwangi \\ E-mail: harismujianto09@gmail.com ${ }^{1)}$, miftadoni@yahoo.co.id ${ }^{2)}$
}

\begin{abstract}
ABSTRAK
Ayakan getar (vibrating screen) banyak digunakan dalam proses pemilahan bahan sesuai ukuran yang dikehendaki. Peralatan ini diaplikasikan di dunia industri maupun di laboratorium. Penelitian ini bertujuan untuk mendapatkan pengaruh sudut kemiringan terhadap unjuk kerja ayakan getar. Unjuk kerja ayakan getar didefinisikan sebagai laju aliran hasil ayakan. Penelitian dilakukan dengan eksperimen. Peralatan ayakan getar berukuran panjang $150 \mathrm{~cm}$ dan lebar $30 \mathrm{~cm}$. Ayakan terdiri dari 3 bagian yaitu ayakan halus, sedang dan kasar. Bahan yang digunakan adalah pasir sesuai ukuran ayakan dengan berat masing-masing $1 \mathrm{~kg}$. Sudut kemiringan divariasikan sebesar $5^{\circ}, 10^{\circ}, 15^{\circ}, 20^{\circ}$ dan $25^{\circ}$. Sumber gerak digunakan motor listrik dengan variasi kecepatan putar 1000, 1200 dan $1450 \mathrm{rpm}$. Laju aliran massa bahan divariasikan dengan katup geser pada hopper sebesar 5, 10 dan 15 gram/detik. Pengambilan data dilakukan sebanyak 3 kali ulangan untuk masing-masing percobaan. Data hasil penelitian dihitung nilai rata-ratanya. Laju hasil ayakan merupakan hasil bagi berat bahan dan lama pemrosesan. Hasil penelitian menunjukkan bahwa sudut kemiringan ayakan getar berpengaruh terhadap hasil ayakan. Semakin besar sudut kemiringan maka waktu proses menjadi semakin kecil. Semakin besar sudut kemiringan maka laju pengayakan bahan menjadi semakin besar.
\end{abstract}

Kata kunci : ayakan getar, sudut kemiringan, unjuk kerja, laju hasil ayakan

\begin{abstract}
Vibrating screen used in material separation process. This equipment is used in industry and also at laboratorium. This research is aimed to get the effect of angle inclination due to vibrating screen performance. The research is done by experiment. Vibrating screen with $150 \mathrm{~cm}$ length and $30 \mathrm{~cm}$ wide consist 3 sections which are fine, medium and rough. The material used are sand with each $1 \mathrm{~kg}$ as the screen size. Angle inclination is vary as $5^{\circ}, 10^{\circ}, 15^{\circ}, 20^{\circ}$ and $25^{\circ}$. Vibrating screen motion is a electric motor with rotating speed 1000, 1200 and $1450 \mathrm{rpm}$. Mass flow rate is vary by hopper sliding valve as 5, 10 dan $15 \mathrm{gram} / d e t i k$. The data are taken 3 times to get average values. Sieving flow rate is a ration between material weight and process time. The result shows that angle inclination has effect due sieving performance. The angle increasing tend to lower process time. The angle increasing tend to raise sieving flow rate.
\end{abstract}

Keywords: vibrating screen, angle inclination, performance, sieving flow rate 


\section{PENDAHULUAN}

Proses pemilahan bahan banyak dilakukan untuk memisahkan material sesuai ukuran atau kategori yang dikehendaki. Perkembangan teknologi dan upaya peningkatan produktivitas mendorong pemanfaatan peralatan mekanis dalam proses ini. Tingkat kebutuhan manusia yang semakin meningkat juga menjadi faktor pendorong perkembangan peralatan tersebut. Salah satu peralatan mekanis yang digunakan adalah ayakan getar (vibrating screen). Proses pemilahan dengan ayakan getar merupakan salah satu metode tertua dan banyak digunakan secara luas dalam proses pemilahan secara fisik. Aplikasi ini dilakukan di dunia industri dalam pemilahan skala besar maupun di laboratorium sebagai alat bantu skala kecil untuk analisa distribusi ukuran partikel [3]. Di dunia industri, ayakan getar digunakan di bidang pertambangan, powder metallurgy, proses kimia dan konstruksi [5].

Ayakan getar bekerja dengan gerak vertikal dan horisontal bolak-balik dalam mekanismenya [7]. Gerakan ini menimbulkan efek gerak memantul (bumping) pada bahan atau material yang diproses. Peralatan ini pertama kali digunakan di Amerika pada awal abad ke 20 dan berkembang dari segi efisiensi, terutama di Jerman pada pertengahan abad ke 20 [4].

Unjuk kerja sebuah ayakan getar tergantung pada faktor material yang diproses dan faktor peralatan atau mesin tersebut. Faktor material berhubungan dengan sifat-sifat mekanik material antara lain ukuran, bentuk, densitas, kadar air dan lain-lain [7]. Faktor mesin terutama berkaitan dengan intensitas getaran yang terjadi dan dapat mempengaruhi efektifitas proses pengayakan [8].

Upaya peningkatan unjuk kerja ayakan getar telah banyak dilakukan. Hal ini dilakukan dengan penelitian secara analisis deskripsi, simulasi numerik, rancang bangun maupun eksperimen. Analisis deskripsi dilakukan untuk mendapatkan kecepatan gerak partikel di ayakan getar [1]. Simulasi ayakan getar dilakukan dengan Discrete Element Method (DEM) untuk mendapatkan gerakan partikel di ayakan [3].

Penelitian tentang kajian kinematika untuk efisiensi ayakan getar. Ayakan tunggal berukuran $234 \mathrm{x}$ $238 \mathrm{~mm}$. Ukuran lubang ayakan 4,6 x 4,6 mm. Bahan yang diproses adalah campuran 1900 gram debu dan 600 gram butiran berbentuk kerucut. Hasil penelitian menunjukkan bahwa arah frekuensi kerja (winch) sangat berpengaruh terhadap unjuk kerja alat. Demikian pula halnya dengan kecepatan frekuensi kerja tersebut. Ukuran bahan yang diproses juga sangat berpengaruh. Efisiensi optimum dicapai pada kondisi sudut kemiringan ayakan sebesar 10-18 ${ }^{\circ}$ [5].

Rancang bangun dan eksperimen ayakan getar dilakukan untuk pemisahan menir. Mesin pemisah menir yang menggunakan diameter puli sabuk 5 inchi dan kemiringan alat $20^{\circ}$. Uji coba alat dilakukan dengan 3 kali ulangan. Hasil pengujian menunjukkan bahwa diperoleh kapasitas mesin adalah $100 \mathrm{~kg} / \mathrm{jam}$ [2].

Penelitian eksperimen pengayak getar dengan memvariasikan putaran motor penggerak mekanisme engkol peluncur dan aliran massa abu sekam padi masuk ayakan untuk mendapatkan data-data simpangan koordinat pegas yang bergetar dan simpangan titik berat pengayak getar. Hasil penelitian menunjukkan bahwa laju hasil pengayakan abu sekam padi yang tertinggi pada putaran motor $2430 \mathrm{rpm}$ dengan laju massa hasil ayakan yang optimal sebesar $1.49 \mathrm{gr} / \mathrm{dt}$ [9]

Perancangan mesin pengayak pasir cetak vibrating screen pada IKM cor di Juwana kabupaten Pati. Pasir merupakan satu bahan pokok untuk pembuatan cetakan di industri pengecoran. Kapasitas alat dirancang sebesar $500 \mathrm{~kg} / \mathrm{jam}[6]$.

Sudut kemiringan (inklinasi) ayakan akan berpengaruh terhadap mekanisme gerak akibat getaran yang terjadi. Selain itu, sudut kemiringan merupakan salah satu faktor yang akan berpengaruh terhadap gerak partikel [5]. Gerak partikel ini kan berpengaruh terhadap unjuk kerja atau efisiensi ayakan getar. Untuk itu perlu dilakukan penelitian pengaruh sudut kemiringan (inklinasi) ayakan getar.

Ayakan getar digunakan secara luas di dunia industri maupun riset skala laboratorium. Peralatan mekanik ini sangat dibutuhkan untuk proses pemilahan bahan atau material. Proses yang dilakukan secara optimum akan meningkatkan unjuk kerja atau efisiensi ayakan getar tersebut. Efisiensi ini selanjutnya akan berdampak pada konsumsi energi listrik sebagai sumber tenaga penggerak mekanisme ayakan getar. Penelitian ini bertujuan untuk mendapatkan pengaruh sudut kemiringan (inklinasi) terhadap unjuk kerja ayakan getar. 


\section{TINJAUAN PUSTAKA}

\subsection{Ayakan Getar}

Pengayakan merupakan satuan proses pemisahan dari berbagai ukuran bahan untuk dipisahkan ke dalam 2 atau 3 kategori dengan menggunakan ayakan. Setiap kategori yang keluar dari ayakan mempunyai ukuran yang seragam [6]. Ayakan getar merupakan suatu peralatan dengan gerak mekanik yang memanfaatkan gaya-gaya eksitasi guna memisahkan material berdasarkan ukuran butir material yang dikehendaki. Pada umumnya pengayak getar mengunakan poros eksentris untuk menghasilkan gaya eksitasi [9].

Getaran yang terjadi di ayakan getar merupakan gerak bolak-balik yang menimbulkan efek gerak memantul (bumping) pada bahan atau material yang diproses. Gerak partikel di atas ayakan terbagi dalam 3 area utama sebagai fungsi dari panjang ayakan yaitu hubungan partikel terhadap laju aliran bahan, fase pembentukan fraksi dan fase pemisahan [4].

Aliran material sepanjang ayakan akan membentuk lapisan material yang ketebalannya merupakan fungsi dari laju aliran material tersebut. Partikel dengan ukuran yang lebih kecil cenderung untuk berada di lapisan bawah. Partikel berukuran lebih besar akan membentuk lapisan ganda (double layer) konsentrasi tinggi di atas ayakan [3].

\subsection{Unjuk Kerja Ayakan Getar}

Dalam eksperimen, unjuk kerja ayakan getar dapat didefinisikan sebagai laju massa hasil ayakan optimal [9]. Hal ini dapat dilakukan dengan melakukan pengukuran terhadap massa bahan yang diproses dan lama waktu pemrosesan. Unjuk kerja ayakan getar dipengaruhi oleh [8]: a. Ukuran dan bentuk lubang ayakan.

b. Ukuran dan bentuk partikel.

c. Prosentase ukuran material.

d. Kadar air material.

e. Prosentase area bebas pada ayakan.

f. Kecepatan gerak ayakan.

g. Sudut kemiringan ayakan.

h. Intensitas getaran ayakan (amplitudo dan frekuensi).

i. Laju aliran material ke ayakan.

j. Panjang ayakan.

\section{METODE PENELITIAN}

\subsection{Variabel Penelitian}

Variabel bebas meliputi sudut kemiringan ayakan $\alpha\left(5^{\circ}, 10^{\circ}, 15^{\circ}, 20^{\circ}\right.$ dan $\left.25^{\circ}\right), 3$ variasi laju aliran bahan dengan bukaan katup geser (5, 10 dan 15 gr/detik) dan 3 variasi putaran motor penggerak $(1000 \mathrm{rpm}, 1200 \mathrm{rpm}$ dan $1450 \mathrm{rpm})$. Variabel terikat yaitu prosentase hasil ayakan dan laju hasil ayakan. Bahan yang digunakan adalah pasir kali sebanyak masing-masing $1 \mathrm{~kg}$ untuk 3 ukuran ayakan. Pengambilan data dilakukan dengan 3 kali ulangan.

\subsection{Peralatan Penelitian}

Ayakan getar dibuat dengan ukuran panjang 150 $\mathrm{cm}$ dan lebar $30 \mathrm{~cm}$. Panjang $150 \mathrm{~cm}$ dibagi menjadi 3 bagian masing-masing $50 \mathrm{~cm}$ untuk ayakan halus, ayakan sedang dan ayakan kasar. Gerakan alat dilakukan dengan mekanisme engkol yang digerakkan dengan sebuah motor listrik. Pengaturan putaran motor listrik dilakukan untuk variasi gaya eksitasi pada ayakan.

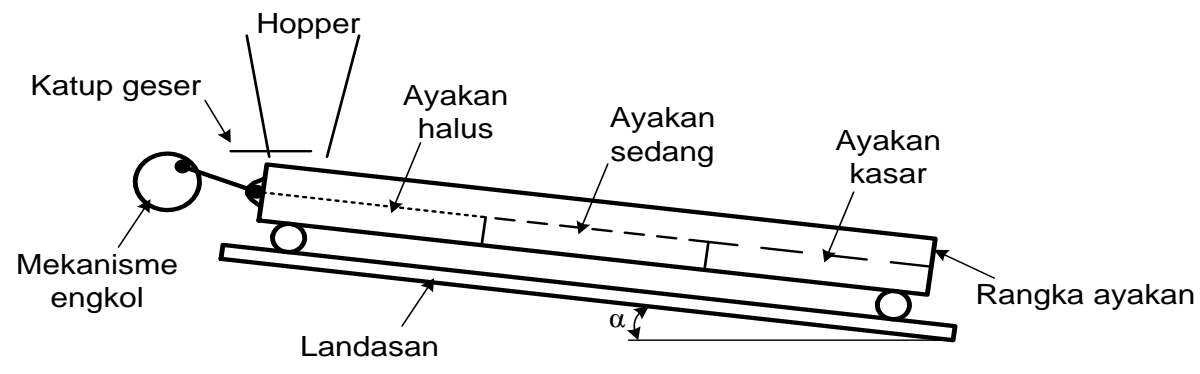

Gambar 1. Skema Peralatan Penelitian 


\subsection{Langkah Pengambilan Data}

1. Melakukan pengaturan laju aliran massa bahan dengan pengukuran berat dan waktu. Pengaturan dilakukan dengan variasi bukaan katup geser.

2. Persiapan campuran bahan pasir sesuai dengan beratnya. Bahan dengan 3 jenis kekasaran dicampur dengan mixer.

3. Bahan pasir dimasukkan ke dalam hopper. Katup geser pada posisi tertutup penuh.

\section{HASIL DAN PEMBAHASAN}

Hasil pengambilan data 3 ulangan dihitung nilai rata-ratanya. Hasil perhitungan dapat dilihat pada tabel 1. Bahan pasir dengan 3 kategori ukuran masing-masing seberat $1 \mathrm{~kg}$ sehingga total berat 3000 gram. Waktu ratarata pada tabel 1 adalah waktu total untuk proses ayakan dengan 3 ukuran ayakan. Laju proses ayakan dihitung
4. Motor listrik dihidupkan dan dilakukan pengaturan putaran dengan potensiometer.

5. Katup geser dibuka untuk mengalirkan bahan.

6. Melakukan percobaan sampai semua bahan selesai diproses.

7. Melakukan pengukuran berat pasir setelah proses.

8. Mencatat lama waktu pemrosesan.

9. Melakukan ulangan sebanyak 3 kali.

10. Mengulangi percobaan untuk variasi yang lain.

dengan cara membagi berat bahan dengan waktu proses. Misal untuk data sudut ayakan $5^{\circ}$, putaran $1000 \mathrm{rpm}$ dan laju pemasukan bahan $5 \mathrm{gr} / \mathrm{dt}$ :

$$
\begin{aligned}
\dot{m} & =\frac{(3000 / 243,76)}{3} \\
& =4,10 \mathrm{gr} / \mathrm{dt}
\end{aligned}
$$

Dengan cara yang sama didapat hasil perhitungan seperti pada tabel 2.

Tabel 1. Waktu Proses Rata-Rata (Detik)

\begin{tabular}{cccccccccc}
\hline \multirow{2}{*}{$\begin{array}{l}\text { Sudut } \\
\text { Ayakan }\left({ }^{\circ}\right)\end{array}$} & \multicolumn{3}{c}{$1000 \mathrm{rpm}$} & \multicolumn{3}{c}{$1200 \mathrm{rpm}$} & \multicolumn{3}{c}{$1450 \mathrm{rpm}$} \\
\hline 5 & 243.76 & $10 \mathrm{gr} / \mathrm{dt}$ & $15 \mathrm{gr} / \mathrm{dt}$ & $5 \mathrm{gr} / \mathrm{dt}$ & $10 \mathrm{gr} / \mathrm{dt}$ & $15 \mathrm{gr} / \mathrm{dt}$ & $5 \mathrm{gr} / \mathrm{dt}$ & $10 \mathrm{gr} / \mathrm{dt}$ & $15 \mathrm{gr} / \mathrm{dt}$ \\
\hline 10 & 241.08 & 161.02 & 114.95 & 234.96 & 150.01 & 109.68 & 235.41 & 149.98 & 108.41 \\
15 & 240.64 & 162.82 & 113.07 & 237.06 & 149.78 & 107.44 & 231.63 & 145.52 & 106.62 \\
20 & 226.93 & 160.69 & 111.95 & 226.47 & 145.26 & 105.28 & 225.96 & 143.56 & 102.86 \\
25 & 221.43 & 157.52 & 109.74 & 220.19 & 143.04 & 104.21 & 219.08 & 138.12 & 98.74 \\
\hline
\end{tabular}

Tabel 2. Laju Aliran Massa Ayakan (gr/dt)

\begin{tabular}{cccccccccc}
\hline Sudut & \multicolumn{3}{c}{$1000 \mathrm{rpm}$} & \multicolumn{3}{c}{$1200 \mathrm{rpm}$} & \multicolumn{3}{c}{$1450 \mathrm{rpm}$} \\
\cline { 2 - 11 } Ayakan $\left({ }^{\circ}\right)$ & $5 \mathrm{gr} / \mathrm{dt}$ & $10 \mathrm{gr} / \mathrm{dt}$ & $15 \mathrm{gr} / \mathrm{dt}$ & $5 \mathrm{gr} / \mathrm{dt}$ & $10 \mathrm{gr} / \mathrm{dt}$ & $15 \mathrm{gr} / \mathrm{dt}$ & $5 \mathrm{gr} / \mathrm{dt}$ & $10 \mathrm{gr} / \mathrm{dt}$ & $15 \mathrm{gr} / \mathrm{dt}$ \\
\hline 5 & 4.10 & 5.99 & 8.70 & 4.26 & 6.67 & 9.12 & 4.25 & 6.67 & 9.22 \\
10 & 4.15 & 6.21 & 8.71 & 4.25 & 6.78 & 9.16 & 4.29 & 6.80 & 9.32 \\
15 & 4.16 & 6.14 & 8.84 & 4.22 & 6.68 & 9.31 & 4.32 & 6.87 & 9.38 \\
20 & 4.41 & 6.22 & 8.93 & 4.42 & 6.88 & 9.50 & 4.43 & 6.97 & 9.72 \\
25 & 4.52 & 6.35 & 9.11 & 4.54 & 6.99 & 9.60 & 4.56 & 7.24 & 10.13 \\
\hline
\end{tabular}




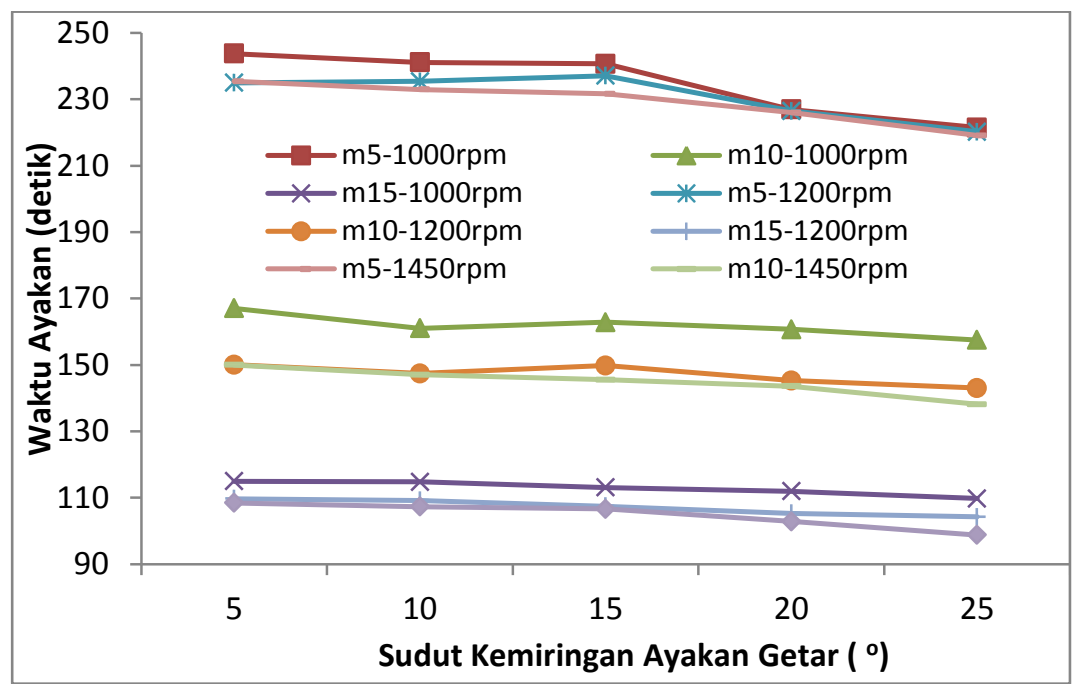

Gambar 2. Grafik Waktu Ayakan

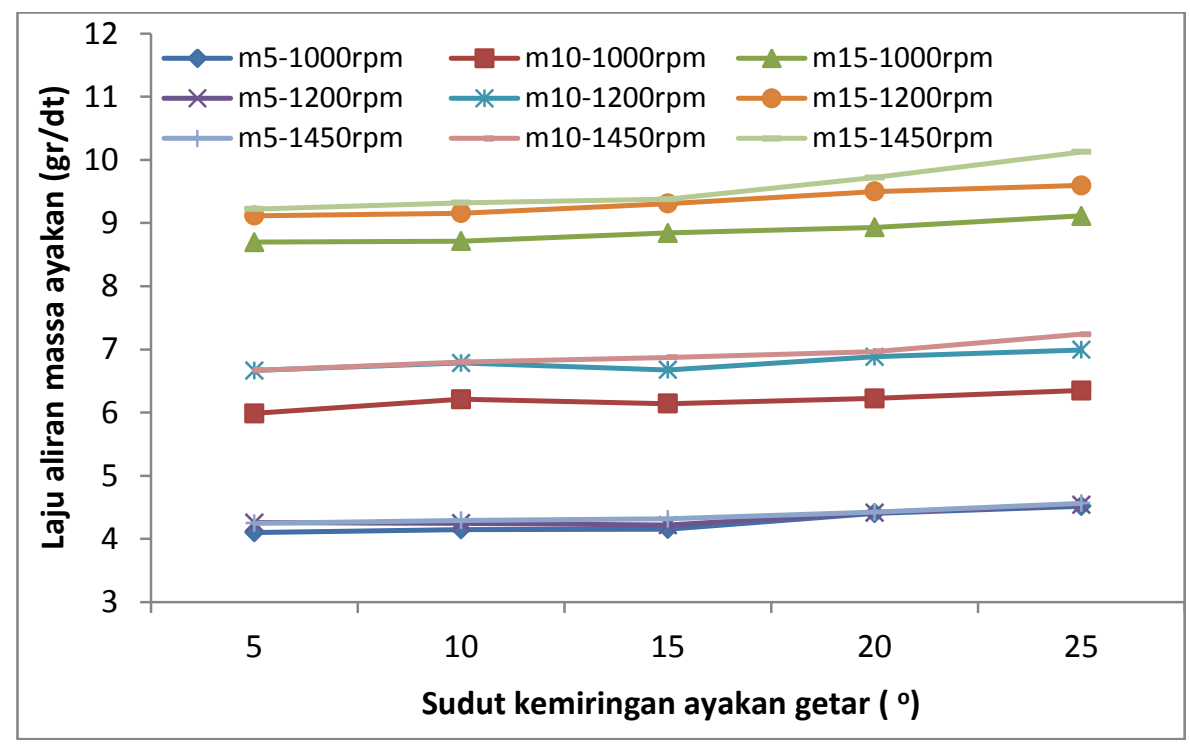

Gambar 3. Grafik Laju Aliran Massa Ayakan

Grafik pada gambar 2 menunjukkan bahwa waktu ayakan cenderung semakin kecil jika sudut kemiringan ayakan semakin besar. Sudut kemiringan ayakan yang besar akan menyebabkan aliran bahan turun ke posisi lubang ayakan semakin cepat. Sudut kemiringan ini juga menyebabkan efek gerak memantul (bumping) pada bahan juga semakin besar.

Grafik tersebut juga menunjukkan bahwa semakin besar laju aliran bahan ke hopper maka waktu ayakan cenderung semakin kecil. Laju aliran bahan yang semakin besar berarti bahan yang masuk ke proses ayakan juga semakin banyak. Hal ini menyebabkan hasil ayakan semakin banyak dan waktunya menjadi semakin cepat.

Grafik tersebut juga menunjukkan bahwa semakin besar putaran maka waktu ayakan cenderung semakin kecil. Putaran motor penggerak menghasilkan gaya eksitasi sehingga putaran yang lebih besar akan menghasilkan frekuensi gerak ayakan yang semakin besar pula. Gerak yang semakin banyak akan menyebabkan hasil ayakan semakin besar atau waktu ayakan yang semakin kecil. 
Grafik pada gambar 3 menunjukkan bahwa laju aliran massa ayakan cenderung meningkat jika sudut kemiringan ayakan semakin besar. Grafik juga menunjukkan bahwa laju aliran massa ayakan cenderung meningkat jika laju aliran bahan ke hopper semakin besar besar. Grafik juga menunjukkan bahwa laju aliran massa ayakan cenderung meningkat jika putaran motor penggerak semakin besar besar. Hal ini sesuai dengan pembahasan pada analisis waktu ayakan.
Sudut kemiringan ayakan getaran menghasilkan gerak memantul bahan yang diproses, laju aliran bahan ke hopper menyebabkan lebih banyak bahan yang diproses dan putaran motor penggerak yang semakin besar akan menyebabkan frekuensi gerak eksitasi semakin besar. Ketiga faktor ini akan menyebabkan hasil ayakan semakin besar sedangkan waktu ayakan akan semakin kecil. Laju ayakan berbanding terbalik dengan waktu ayakan sehingga waktu ayakan yang kecil akan menyebabkan laju ayakan semakin besar.

Tabel 3. Uji Anova

\begin{tabular}{|c|c|c|c|c|c|c|}
\hline & & Sum of Squares & $\mathrm{df}$ & Mean Square & $\mathrm{F}$ & Sig. \\
\hline \multirow[t]{3}{*}{ Laju_ayakan } & Between & 2.123 & 2 & 1.061 & .242 & .78 \\
\hline & Within Groups & 184.302 & 42 & 4.388 & & \\
\hline & Total & 186.425 & 44 & & & \\
\hline \multirow[t]{3}{*}{ Waktu_ayakan } & Between & 882.271 & 2 & 441.136 & .156 & .85 \\
\hline & Within Groups & 118674.298 & 42 & 2825.579 & & \\
\hline & Total & 119556.569 & 44 & & & \\
\hline
\end{tabular}

Waktu ayakan maksimum terjadi pada variasi sudut kemiringan ayakan $5^{\circ}$, laju aliran bahan $5 \mathrm{gr} / \mathrm{dt}$ dan putaran $1000 \mathrm{rpm}$ yaitu sebesar 243,76 detik. Waktu ayakan minimum terjadi pada variasi sudut kemiringan ayakan $25^{\circ}$, laju aliran bahan $15 \mathrm{gr} / \mathrm{dt}$ dan putaran 1450 rpm yaitu sebesar 98,74 detik. Laju aliran massa ayakan maksimum terjadi pada variasi sudut kemiringan ayakan $25^{\circ}$, laju aliran bahan $15 \mathrm{gr} / \mathrm{dt}$ dan putaran $1450 \mathrm{rpm}$ yaitu sebesar 10,13 gram/detik. Waktu ayakan minimum terjadi pada variasi sudut kemiringan ayakan $5^{\circ}$, laju aliran bahan $5 \mathrm{gr} / \mathrm{dt}$ dan putaran $1000 \mathrm{rpm}$ yaitu sebesar 4,10 gram/detik.

Hasil analisis statistik Anova satu arah menggunakan SPSS for windows 17.0 pada tabel 3 menunjukkan bahwa tingkat signifikansi untuk faktor laju ayakan dan waktu ayakan sebesar 0,786 dan 0,856 . Hal ini menunjukkan bahwa pengambilan data yang dilakukan pada penelitian ini telah menghasilkan data dengan tingkat signifikansi yang relatif tinggi.

\section{KESIMPULAN}

1. Sudut kemiringan ayakan getar berpengaruh terhadap hasil ayakan.

2. Semakin besar sudut kemiringan maka waktu proses menjadi semakin kecil.

3. Semakin besar sudut kemiringan maka laju pengayakan bahan menjadi semakin besar.

\section{UCAPAN TERIMA KASIH}

Penelitian ini diselenggarakan dengan biaya penelitian melalui skim Penelitian Dosen Pemula Kemenristek Dikti TA 2015. Contact Person: 085228351198

\section{DAFTAR PUSTAKA}

[1] Dyr T, Wodzinski P, 2002, Model Particle Velocity on a Vibrating Surface. Jurnal Physicochemical Problems of Mineral Processing, 36; hal. 147-157

[2] Juanda, 2010, Rancang Bangun Mesin Pemisah Menir dengan Sistem Getar. Jurnal Teknologi dan Industri Pertanian Indonesia Vol. 2 (1), hal. 15-19

[3] Li J, Webb C, Pandiella SS, Campbell CA, 2003. Discrete Particle Motion on Sieves - a Numerical Study Using the Dem Simulation. Jurnal Powder Technology 133: hal. 190-202

[4] Meinel A, 2010, Fine and Very Fine Screening. Jurnal AT Mineral Processing English Edition Volume 51 
[5] Shen H, Zhang J, Xue C, He B, Liu Y, Yang T, 2011, A "Novel PKM-Based Vibrating Sifter and its Screening Efficiency Experimental Study," dalam Proc. $13^{\text {th }}$ World Congress in Mechanism and Machine Science, Guanajuato, México

[6] Sulistiawan H, Slamet S, 2014, "Perancangan Mesin Pengayak Pasir Cetak Vibrating Screen pada IKM Cor di Juwana Kabupaten Pati," dalam Proc. Snatif Ke -1

[7] Sullivan JF, 2012, Screening Theory and Practice, Triple/S Dynamics Inc

[8] Tsakalakis K, 2001, Some Basic Factors Affecting Screen Performance in Horisontal Vibrating Screen, The European Journal of Mineral Processing and Environmental Protection Vol. 1, hal.42-54

[9] Yanto A, 2013, Analisa Unjuk Kerja Pengayak Getar Sebagai Sistem Getaran Dua Derajat Kebebasan Terhadap Pengayakan Abu Sekam Padi, Jurnal Momentum Vol.15 (02), hal,125-129 